Dr. sc. Hrvoje Vojković

\title{
GRAĐANSKOPRAVNI STANDARD MEDICINSKOG TRETMANA
}

\author{
UDK: $347: 614$ \\ DOI: $10.31141 /$ zrpfs.2019.56.133.567 \\ Pregledni znanstveni rad \\ Primljeno: 1. 04. 2019.
}

\begin{abstract}
Istražujući građanskopravni standard obavljanja medicinskog tretmana nastojalo se utvrditi može li se medicinska usluga kvalitativno ili na drugi način diferencirati s obzirom na dob ili spol pacijenta ili se jedinstveno primjenjuje u svojoj punini uz neke specifičnosti. Medicinski standard iskazuje se u dimenziji temeljnog ili osnovnog standarda koji pretpostavlja primjenu jednoznačnih pravila kojih se mora pridržavati svaki liječnik, ali istovremeno u medicinski standard spadaju i svi drugi postupci liječnika koji su rezultat novijih znanstveno-medicinskih spoznaja i primjenjuju se u širem krugu profesionalne zajednice. Pri obavljanju medicinskog postupka liječnik je dužan postupati s pažnjom koja se traži za osobe koje pripadaju istom profesionalnom krugu. Sukladno tome, hrvatsko pozitivno pravo od liječnika traži da postupa prema standardu dobrog, a ne tek prosječnog stručnjaka, a povredu tako nametnutog profesionalnog standarda određuje kao štetnu radnju s obilježjem protupravnosti u subjektivnom smislu.
\end{abstract}

Ključne riječi: standard medicinskog tretmana, liječnička pogreška, ugovor o zdravstvenoj usluzi, građanskopravna odgovornost liječnika, dužna pažnja liječnika, standard dobrog stručnjaka

\section{UVOD}

\subsection{OPĆENITO}

Tematika pridržavanja standarda dužne pažnje liječnika prilikom obavljanja medicinskog tretmana postaje sve važnija u krugovima stručne pa i šire javnosti. Evidentno povećanje interesa za navedenu problematiku najvećim je dijelom posljedica transpozicije određenih pravno-ekonomskih trendova iz područja zapadnih članica Europske unije, a u vezi s građanskopravnom odgovornosti uslijed povrede standarda medicinskog tretmana. Naime, općepoznato je da primjena medicinskih postupaka uvijek sa sobom nosi određeni rizik koji može rezultirati u nastupu štetnih posljedica odnosnog medicinskog tretmana te s time u vezi pravna literatura ${ }^{1}$ upozorava na sve snažniji fenomen denuncijacije i/ili parničenja $\mathrm{u}$ slučajevima kad se presumira odstupanje od zahtijevanog medicinskog standarda.

1 Ferrara, S. D.; Boscolo-Berto., R.; Viel, G. (ur.), Malpractice and medical liability, Springer, Berlin, Heidelberg, 2013., str. 5. 
Tako se ističe da je u proteklom desetljeću zabilježen porast od preko 50 posto te se skreće pozornost na činjenicu da, prema Specijalnom Eurobarometru o medicinskim pogreškama, oko 80 posto građana EU-a percipira medicinske pogreške kao glavno pitanje, a oko 50 posto smatra da će biti osobno oštećeni uslijed povrede medicinskog standarda. Statistike pokazuju da je europsko javno mnijenje postalo svjesno da postoje konkretne i realne opcije koje omogućuju učinkovito ostvarenje prava na naknadu štete u takvim slučajevima, pri čemu je fenomen zabilježio proporcionalno povećanje troškova na ime naknade štete zbog povrede medicinskog tretmana koji su ukupno porasli za cca. 200 posto prema Europskom bolničkom i zdravstvenom savezu, te variraju između 9 i 15 euro per capita. ${ }^{2}$

Interesantno je u ovome kontekstu spomenuti recentnu usporednu analizu kvalitete zdravstvene zaštite u Hrvatskoj i u drugim zemljama Unije (indeks EHCI) koja je pokazala da, neovisno o povremenim javnim kritikama sustava javnog zdravstva u Hrvatskoj, pacijenti ipak u pretežnoj mjeri iskazuju zadovoljstvo radom medicinskog osoblja. U tom smislu valja uputiti na istraživanje Ekonomskog instituta, Zagreb i UNODC-a iz 2010. godine, provedenome na 3000 ispitanika koje je pokazalo da oko 40 posto građana smatra da je kvaliteta usluge koju pružaju liječnici i medicinske sestre u Hrvatskoj "vrlo dobra", a dodatnih 40 posto smatra da je usluga "dobra". Čak 80 posto građana ocijenilo je kvalitetu medicinske usluge $\mathrm{u}$ javnom zdravstvu dobrom i vrlo dobrom, a u istom su istraživanju zdravstveni djelatnici najbolje ocijenjeni javni djelatnici među svim javnim službama u Hrvatskoj. ${ }^{3}$ Usput treba primijetiti da ipak postoji stanovita senzibiliziranost javnosti kad je u pitanju mogućnost povrede medicinskog standarda u pružanju usluge, o čemu svjedoči prethodno citirano istraživanje indeksa EHCI u dijelu ocjene stanja liječničke odgovornosti. ${ }^{4}$ Summa summarum, valja konstatirati da hrvatsku znanstvenu zbilju zasad obilježava nedostatak relevantnih istraživanja i statistike. Tako, primjerice, nije poznat broj aktivnih parničnih postupaka, kao ni koeficijent utuženja radi povrede medicinskog standarda, u odnosu na ukupan

2 European Hospital and Healthcare Federation.

3 Budak, J., „Ocjena pacijenata o kvaliteti rada zdravstvenog osoblja“, u: Vehovec, M. (ur.): $O$ zdravstvu iz ekonomske perspektive; Ekonomski Institut, Zagreb, 2014., str. 275--276.

4 „Slijedom navedenog možemo zaključiti da hrvatska pravna i medicinska praksa nisu usklađene sa praksom u referentnim državama koje smo komparativno obradili jer Hrvatska ne bilježi značajniju pojavu sudskog utuženja šteta koje su posljedica povrede medicinskog standarda. Osim toga, sasvim izostaju relevantna znanstvena istraživanja te statistika "medicinskih šteta", a tek ponekad javnost biva izviještena o nekim drastičnim slučajevima liječničkih pogreški (npr. slučaj Maškarin), koje ukazuju na imperfektnost sustava. Fenomenologija liječničkih pogreški još uvijek nije kolektivno legitimirana kao bitna tema, a razloge tomu valja prvenstveno tražiti u poljima sociologije, socijalne antropologije i psihologije. U hrvatskom društvu je oduvijek zamjetan opći stav prevladavajućeg poštovanja prema liječničkoj struci kao svojevrsnoj humanitarnoj djelatnosti koja prividno nije u sferi komercijalnog. Na hipotetičkoj ljestvici kolektivnog poštovanja, odnos prema liječnicima je čvrsto na drugom mjestu, odmah iza točke respekta prema profesionalnim vjerskim službenicima!“; Prema Vojković, H., Differentiating Medical Malpractice from Medical Complications, Pravni fakultet u Mariboru, Zbornik - rad prihvaceen za objavu u travnju 2019. 
obujam korištenih zdravstvenih usluga. Nasuprot hrvatskom iskustvu, u većini zapadnih članica EU-a i SAD-a situacija je bitno drukčija. ${ }^{5}$

Središnje istraživačko pitanje ovoga rada odnosi se na analizu građanskopravnog aspekta medicinskog standarda prilikom pružanja zdravstvene usluge. U tom smislu, nastojalo se, inter alia, istražiti može li se medicinska usluga kvalitativno ili na drugi način razlikovati s obzirom na dob ili spol pacijenta, odnosno druge posebne okolnosti, ili se jedinstveno primjenjuje u svojoj punini uz neke specifičnosti kao što je, primjerice, pružanje zdravstvene usluge u uvjetima hitnosti. Općenito, medicinski standard zdravstvene usluge zasniva se na općoj obvezi liječnika da tijekom medicinskog tretmana poštuje odgovarajući medicinski protokol te da primijeni standard dužne pozornosti koja odgovara njegovoj profesiji i dodatnoj specijalizaciji. Sukladno tome, pozitivno pravo RH normira načelo učinkovitosti $i$ djelotvornosti sustava kvalitete zdravstvene zaštite i sigurnosti zdravstvenih postupaka, te prihvaća sintagmu kvaliteta zdravstvene zaštite koja neizravno utječe na oblikovanje konstrukcije medicinskog standarda in praxi. Tako navedeni pojam obuhvaća rezultat mjera koje se trebaju poduzimati sukladno suvremenim spoznajama u zdravstvenim postupcima, a koje osiguravaju najviši mogući povoljan ishod liječenja i smanjenje rizika za nastanak neželjenih posljedica na zdravlje ljudi.

$\mathrm{U}$ ostvarenju cilja rada istraženi su konstitutivni elementi građanskopravne konstrukcije medicinskog standarda liječnika. U okviru provedene analize utvrđen je sadržaj pojma pravno relevantnog medicinskog standarda i to na osnovi imaginarnog modela ponašanja liječnika u okviru medicinskog tretmana in concreto, pri čemu mjerilo ponašanja nije prosječno pametna i pažljiva osoba, već uobičajeno pažljiv liječnik. Drugim riječima, kako će u daljnjem istraživanju ukazati hrvatska i komparativna teorija i praksa, zahtijevani prosječan standard medicinskog postupanja nije prosječan standard građanina, nego prosječan standard

„Svojedobno istraživanje u dvije zdravstvene ustanove u SAD-u (1999. g.), pokazalo je da čak 2,9\%, odnosno 3,9\% bolesnika trpi povredu zdravlja što je u kauzalnoj vezi sa provedenim medicinskim tretmanom, dok u Danskoj taj postotak iznosi visokih 9\%, u Francuskoj 8,9\%, a u Velikoj Britaniji 11. Ilustrativan je podatak da su posljedice liječničkih pogreški osmi uzrok smrti u SAD-u. Referentna međunarodna literatura upućuje na trend "povećanja sklonosti traženja odštete", a pacijenti sve češće izražavaju prigovore na rad liječnika te se otkrivaju ozbiljne povrede pravila medicinske struke koje su trebale biti unutarnjim kontrolama ranije uočene i otklonjene, ali ne upućuju nužno i na nisko povjerenje pacijenata u liječnike. Na području SAD i EU (napose u nekim zemljama poput Italije), već možemo govoriti o pravoj industriji liječničke odgovornosti koja u SAD producira kumulativni godišnji izdatak po različitim osnovama od \$17-29 milijardi godišnje, prema američkom Institute of Medicine. Prema drugom istraživanju posljedice liječničkih pogreški u SAD pretekle su štete izazvane prometnim nezgodama te godišnje oštećuju više od 1,5 milijuna američkih pacijenata. S druge strane u Velikoj Britaniji bilježi se značajan porast odštetnopravnih postupaka kojih je 1978.g. bilo tek otprilike 500 u odnosu na čak 7000 u razdoblju 1990 - 1991.g. sa daljnjim rastućim trendovima u današnje vrijeme. Na istovjetne trendove autori upućuju kad je u pitanju Italija, te se izvještava o 50\% povećanju broja parnica radi popravljanja štete zbog liječničke pogreške u vremenu između 1980 - 1986 sa evidentiranim dodatnim porastom od $90 \%$ u 1987. Tako se u Italiji na godišnjoj razini pokreće otprilike 15.000 odštetnopravnih postupaka uslijed šteta uzrokovanih liječničkom pogreškom, a zdravstvene ustanove na ime odštetnine pacijentima isplaćuju ukupni iznos od cca. EUR 10 milijardi."; Prema, Vojković, H., Differentiating Medical Malpractice from Medical Complications, Pravni fakultet u Mariboru, Zbornik - rad prihvaćen za objavu u travnju 2019. 
koji vrijedi za liječnike - bonus pater familias standard, ${ }^{6}$ odnosno ars medica standard, ${ }^{7}$ pri čemu se uvijek posebno procjenjuje postupanje liječnika s obzirom na konkretne okolnosti kako bi se rekognoscirala eventualna povreda dužne pažnje ${ }^{8}$ koja bi nedvosmisleno uputila na postojanje krivnje kao subjektivnog elementa protupravnosti i pretpostavke nastanka građanskopravne odgovornosti.

Znanstvenoistraživačke metode primijenjene u ovome znanstvenom radu jesu komparativna i induktivna metoda. Odgovarajućom primjenom navedenih metoda ustanovljen je relevantan građanskopravni okvir za pružanje medicinske usluge lege artis unutar hrvatskog pozitivnog prava i poredbenim pravnim porecima. Rad je strukturiran na način da je uvodno dan osvrt na ukupni pravni i socioekonomski kontekst pružanja usluge medicinskog tretmana sukladno zahtijevanom medicinskom standardu, kao i u inačici contra lege artis s posljedicom građanskopravne odgovornosti za štetu zbog liječničke pogreške. Zaključno je izložena opća konstrukcija medicinskog standarda koja proizlazi iz normi pozitivnog prava te normi strukovnih medicinskih asocijacija, a poseban naglasak stavljen je na definiciju pravnog standarda dužne pažnje liječnika u hrvatskom pravu. U tom dijelu istraživanja iznesen je presjek karakterističnih slučajeva i pravnoteorijskih razmatranja.

\section{MEDICINSKI STANDARD PRUŽANJA USLUGE LIJEČNIČKOG TRETMANA}

\subsection{OPĆENITO}

Medicinski standard obavljanja usluge medicinskog tretmana počiva na imperativu da liječnik u svakom pojedinačnom slučaju mora poštovati odgovarajući medicinski protokol te da mora primijeniti zahtijevani standard dužne pozornosti koja odgovara njegovoj profesiji. Valja naglasiti kako se medicinski standard ne može diferencirati s obzirom na dob i spol pacijenta ili druge kriterije, te se jedinstveno primjenjuje u svojoj punini uz neke specifičnosti koje dolaze donekle do izražaja u slučajevima autonomije maloljetnog pacijenta, pacijenta bez svijesti, u neodgodivim medicinskim postupcima i dr.

Određivanje sadržaja medicinskog standarda treba uzeti u obzir činjenicu da medicina nije egzaktna znanost i da rezultati medicinskih zahvata u određenoj mjeri redovito nisu sasvim predvidljivi. Treba uzeti u obzir da je medicinska znanost „progresivna znanost” koju karakterizira sve naglašeniji trend specijalizacije i subspecijalizacije. Detaljnije pravno određenje standarda medicinskog postupanja

6 Faure, M., „Economic observations concerning optimal prevention and compensation of damage caused by medical malpractice“", u: Dute, J.; Faure, M. G.; Koziol, H. (ur.), No-fault compensation in the health care sector, Springer, Wien; New York, 2004., str. 19.

7 Ferrara, S. D.; Boscolo-Berto; R., Viel, G. (ur.), op. cit. u bilj. 1, str.77.

8 Petrić, S., „Građanskopravna odgovornost zdravstvenih djelatnika“, Zbornik Pravnog fakulteta Sveučilišta u Rijeci, god. 26, br. 1, 2005., str. 123. 
omogućuje Zakon o kvaliteti zdravstvene zaštite i socijalne skrbi ${ }^{9}$ koji uvodi termin kvaliteta zdravstvene zaštite pod kojom podrazumijeva rezultat mjera koje se trebaju poduzimati sukladno suvremenim spoznajama u zdravstvenim postupcima, a koje osiguravaju najviši mogući povoljan ishod liječenja i smanjenje rizika za nastanak neželjenih posljedica na zdravlje ljudi. Prema citiranom propisu, standardi kvalitete zdravstvene zaštite jesu precizni kvantificirani opisi mjerila u vezi s obavljanjem zdravstvenih postupaka, zdravstvenim radnicima, opremom, materijalima i okolišem u kojem se obavljaju zdravstveni postupci, a kojima se osigurava kvaliteta zdravstvene zaštite.

Liječnik mora biti posjednik stručnog znanja i kompetencije kako bi jamčio provođenje medicinskog tretmana sukladno pravilima medicinske profesije koje se zasnivaju na stručnom standardu postupanja iskusnog liječnika u okviru odgovarajuće medicinske specijalizacije. ${ }^{10}$ Može se ustvrditi da se medicinski standard u svakom slučaju iskazuje u dimenziji temeljnog ili osnovnog standarda koji pretpostavlja primjenu jednoznačnih pravila kojih se mora pridržavati svaki liječnik, primjerice, higijenskih pravila prilikom operativnih zahvata, ali istovremeno u medicinski standard spadaju i svi drugi postupci liječnika koji su rezultat novijih znanstvenomedicinskih spoznaja i primjenjuju se u širem krugu liječničke profesionalne zajednice. ${ }^{11}$

Progresivna priroda medicine i njena posljedična dinamička dimenzija uvjetuju stanovite teškoće u finalnoj definiciji medicinskog standarda. To stoga što je podložan stalnoj promjeni u korelaciji sa stjecanjem novih spoznaja na području medicinske znanosti i razvoja novih praktičnih metoda. Dakle, fenomen dinamizma medicinskog standarda dovodi do nemogućnosti potpunog standardiziranja medicine. Naime, upozorava se na činjenicu da metode koje se ispituju u specijalnim klinikama ne predstavljaju obvezatan standard, a u isto vrijeme u praksi su u primjeni metode $\mathrm{i}$ postupci koji su donekle zastarjeli, pri čemu nije moguće precizno odrediti od kada neki novi medicinski postupak treba inkorporirati u aktualni standard postupanja pri obavljanju medicinskog tretmana. U hrvatskom pravu, Zakon o zdravstvenoj zaštiti uzima u obzir promjenjivu kategoriju profesionalnog medicinskog standarda i utvrđuje pravo i obvezu zdravstvenih djelatnika da se stručno usavršavaju radi održavanja i unapređivanja kvalitete zdravstvene zaštite. ${ }^{12}$

U kontekstu promjenljive prirode medicinskog standarda nameće se dvojba kako bi liječnik trebao postupiti u specifičnim zdravstvenim okolnostima koje isključuju primjenu općeprihvaćenh pravila medicinskog postupanja ili u situaciji kada postoje medicinske okolnosti koje upućuju na provođenje više mogućih

9 Čl. 3. Zakona o kvaliteti zdravstvene zaštite i socijalne skrbi, Narodne novine, br. 124/2011.

10 Ferrara, S. D.; Boscolo-Berto., R.; Viel, G. (ur.), op. cit. u bilj. 1, str. 76-77.

11 Kullmann, H. J., Übereinstimmungen und Unterschiede im medizinischen, haftungsrechlichen und sozialversicherungsrechtlichen Begriff des medizinischen Standards, Versicherungsrecht, br. 13, 1997. str. 529.

12 Čl. 138. Zakona o zdravstvenoj zaštiti, Narodne novine, br. 150/2008, 155/2009, 71/2010, 139/2010, 22/2011, 84/2011, 154/2011, 12/2012, 35/2012, 70/2012, 144/2012, 82/2013, 159/2013, 22/2014, 154/2014, 70/2016, 131/2017. 
varijanti općeprihvaćenih medicinskih tretmana. U takvoj situaciji pravna je teorija stajalište da je liječnik obvezan pružiti zdravstvenu uslugu tek nakon što je prethodno razmotrio sve okolnosti medicinskog slučaja i uzeo u obzir sve povoljne i nepovoljne momente koji se tiču dijagnoze ili planiranog medicinskog tretmana, jer se tada radi o liječniku koji postupa noseći se s vlastitom profesionalnom odgovornosti i teretom dokazivanja da njegovo postupanje u konkretnom slučaju odgovara zakonski prihvaćenoj praksi u vrijeme kada je poduzeto. ${ }^{13}$

Na objektivna aplikativna ograničenja medicinskog standarda ne utječe samo spoznaja da isti predstavlja permanentno promjenljivu kategoriju, već također i činjenica da medicinski standard nema kapacitet upravljanja medicinskim postupkom u njegovu totalitetu s obzirom na pravila profesionalne autonomije liječnika. Naime, liječnik, neovisno o medicinskom standardu, uvijek ima pravo na slobodu izbora odgovarajuće terapije koja se očituje u tri elementa: (1) liječnik odlučuje je li liječenje uopće potrebno; (2) ne smije biti prisiljen primijeniti metode ili medikamente koji proturječe njegovoj savjesti; (3) slobodan je izabrati one dijagnostičke ili terapijske mjere za koje vjeruje da su za konkretnog pacijenta najprimjerenije i najdjelotvornije. Od liječnika se ne zahtijeva izbor najsigurnijeg terapeutskog puta, već bit odgovornog izbora valja tražiti u savjesnom odmjeravanju načela koristi i rizika. ${ }^{14}$ Pravni ce poredak kao medicinski standard prihvatiti samo takvu medicinsku praksu koja je razumna s obzirom na okolnosti individualnog slučaja, pri čemu postojanje nerazumnih medicinski praksi, bez obzira na mogućnost da se radi o postupcima koji su s obzirom na vrijeme i mjesto generalno prihvaćeni, neće osloboditi liječnika profesionalne odgovornosti. ${ }^{15} \mathrm{U}$ praksi se potvrđuje izneseno gledište te se ističe da ako postoji uobičajena praksa s inherentnim poremećajem, činjenica da je široko i općenito prihvaćena kroz duži vremenski period ne čini je nimalo manje nesavjesnom, nepažljivom, a zanemarivanje dužnosti, postupanje bez dužne pažnje, neće nestati ponavljanjem nepažljivog postupanja. ${ }^{16}$

U pogledu primijenjene metode liječenja, od liječnika se očekuje da izabere takvu terapeutsku metodu koja u najvećoj mogućoj mjeri smanjuje rizik od nastupa medicinske komplikacije, odnosno da prihvati metodu koja u cijelosti isključuje mogućnost nastupa štetne posljedice za zdravlje pacijenta. Primjena određenog medicinskog postupka koji je usklađen sa zahtijevanim medicinskim standardom u pojedinoj oblasti medicine isključuje građanskopravnu odgovornost, pa i u situaciji kada kao posljedica liječničke intervencije nastupe neke medicinske komplikacije koje su u svezi s uobičajenim rizikom poduzimanja odnosnog medicinskog zahvata. ${ }^{17} \mathrm{U}$ slučaju hitnosti medicinskog postupanja zbog prijeteće

13 Giesen, D., International medical malpractice law: a comparative law study of civil liability arising from medical care, Mohr; Nijhoff, Tübingen, Dordrecht, 1988., str. 33.

14 Laufs, A.; Uhlenbruck, W., Handbuch des Arztrechts, 3. Auflage, Beck, München, 2002., str.

15 Giesen, op. cit. u bilj. 13, str. 120.

16 Vidi predmet O’Donovan v. Cork County Council (1967) IR 173 (SC), prema Giesen, op. cit. u bilj. 13.

17 VSRH, Rev-6/02-2 od 3. srpnja 2003. 
ugroze zdravlja i/ili života pacijenta, komparativna praksa zauzima stajalište prema kojem zdravstvena organizacija u kojoj je izvršena medicinska intervencija nije u obvezi oštećeniku popraviti štetu što ju je pretrpio kao posljedicu ove intervencije u situaciji kada je kirurška intervencija bila nužna i uz uvjet da je izvedena po svim pravilima medicine. Sukladno tom gledištu, ${ }^{18}$ zdravstvena organizacija unutar koje je obavljena medicinska intervencija može odgovarati samo za one posljedice intervencije koje nastanu uslijed nestručnog, nepažljivog i nepropisnog rada njenih zaposlenika, dakle za posljedice koje se ne mogu pripisati u krivnju liječnicima i drugom medicinskom osoblju zbog postupanja koje ne bi bilo u skladu s pravilima medicinske struke. ${ }^{19}$

U kontekstu moguće građanskopravne odgovornosti za liječničku pogrešku valja posebno istaknuti da realna mogućnost utuženja štete za oštećenog pacijenta predstavlja stalni poticaj daljnjoj profesionalizaciji obavljanja zdravstvene usluge u cilju prevencije neželjenih posljedica što rezultira razvojem kvalitete zdravstvene zaštite. Može se, in generali, uzeti da djelotvoran odštetnopravni sustav ima učinak generalne prevencije od nastupa štetnih događaja, odnosno, djeluje ex ante, što implicite presumira viši prosječan stupanj iskazane stručnosti u provođenju svakodnevnih medicinskih tretmana. ${ }^{20}$

Zaključno treba istaknuti da u hrvatskom pravu medicinsku i pravnu morfologiju važećeg medicinskog standarda, pored ustaljene i općeprihvaćene prakse, u bitnome određuje načelo sigurnosti pacijenata. Navedeno načelo ostvaruje se provedbom mjera kojima se svakom pacijentu osigurava pravo na kvalitetnu zdravstvenu zaštitu sukladno njegovu zdravstvenom stanju i općeprihvaćenim stručnim standardima te kojima se sprečavaju štetni neželjeni događaji čija bi posljedica mogla biti smrt ili oštećenje zdravlja pacijenta. ${ }^{21}$ Uređujući nadalje model ostvarivanja kvalitete zdravstvene zaštite, hrvatsko pozitivno pravo utvrđuje načelo učinkovitosti $i$ djelotvornosti sustava kvalitete zdravstvene zaštite $i$ sigurnosti zdravstvenih postupaka, koje se ostvaruje provedbom mjera za osiguranje kvalitete zdravstvene zaštite čime se postiže optimalan odnos između učinaka provedenih zdravstvenih postupaka i troškova nastalih njihovom provedbom, uvažavajući pritom tehničke, organizacijske i gospodarske čimbenike. ${ }^{22}$

18 Vrhovni sud Srbije, Rev 1832/85 - prema: Milić, D. Obligaciono pravo sa sudskom praksom, D. Milić, Beograd, 1996., str. 96.

19 Vrhovni sud Srbije, Rev 2066/88 - Aktualna sudska praksa iz obl. Odn. „Poslovni biro“, 2000.

20 Vojković, H., Ekonomski učinkovita zdravstvena skrb i liječnička pogreška, znanstveni rad prihvaćen za objavu, Ekonomski pregled, 2018/2019., str. 18.

21 Čl. 5. Zakona o kvaliteti zdravstvene zaštite i socijalne skrbi.

22 Čl. 4. Zakona o kvaliteti zdravstvene zaštite i socijalne skrbi. 


\section{PRAVNI STANDARD DUŽNE PAŽNJE LIJEČNIKA}

\subsection{OPĆENITO}

Obavljanje medicinskog tretmana prema pravilima zdravstvene struke predstavlja temeljnu obvezu koja nastaje u ugovornom odnosu između davatelja i primatelja zdravstvene usluge. Pravila medicinske profesije zahtijevaju od liječnika pažljivo i stručno postupanje što bi mu trebalo omogućiti da postavi ispravnu dijagnozu i uspješno obavi potrebno liječenje. U provođenju medicinskog postupka, dijagnostičkog ili terapeutskog, liječnik je dužan postupati s pažnjom koja se traži za osobe koje pripadaju istom profesionalnom krugu, odnosno s pažnjom dobrog stručnjaka, a ne tek prosječnog stručnjaka, sukladno zahtijevanom medicinskom standardu.

U pitanju standarda dužne pažnje liječnika pojedini pravni poreci koriste sintagmu bonus pater familias, poput Italije, Francuske i Spanjolske, dok drugi, primjerice Velika Britanija i skandinavske zemlje, koriste termin razuman liječnički standard $\mathrm{u}$ korelaciji s prihvaćenim pravilima medicinskog umijeća - ars medica. ${ }^{23}$ U svakom slučaju, profesionalna pažnja, odnosno pažnja dobrog stručnjaka određuje se objektivno, a kao objektivno tipizirani standard pažnje uzima se pažnja koja se može očekivati od iskusnog i savjesnog medicinara istog ranga (njemačko pravo), odnosno dobrog stručnjaka iste kategorije $\mathrm{i}$ istog ranga kao i onoga čije se profesionalno postupanje ocjenjuje (liječnika opće prakse, specijalista i dr., u francuskom pravu) ili reasonably competent doctor (englesko pravo). ${ }^{24}$ Kako bi se ustanovili pravno relevantni kriteriji dužne pažnje liječnika, potrebno je uzeti u obzir kako odnos iskazanog stupnja profesionalne pažnje u odnosu na osobe istog profesionalnog kruga, tako i specifične okolnosti konkretnog medicinskog slučaja. U hrvatskom pravu navedena pravna kategorija dovodi se u vezu s pojmovima kvaliteta zdravstvene zaštite i standardi kvalitete zdravstvene zaštite. ${ }^{25}$

\subsection{PRAVNA KONSTRUKCIJA STANDARDA DUŽNE PAŽNJE LIJEČNIKA}

Postupak determinacije standarda dužne pažnje liječnika polazi od stava da se liječnička nepažnja, nemar sastoji u postupanju liječnika ili pak propuštanju da poduzme sve potrebne radnje koje se tiču medicinskog tretmana nad pacijentom, a koje je profesionalno obvezan poduzeti. Kako je uvodno napomenuto, svaki medicinski tretman može biti poduzet contra legem artis ili, kako neki navode, mala praxis, odnosno kao skrivljeno, nesavjesno postupanje liječnika ukoliko je medicinski zahvat nad pacijentom poduzet bez odgovarajućeg stupnja stručne

23 Ferrara, S. D.; Boscolo-Berto, R.; Viel, G. (ur.), op. cit. u bilj. 1, str. 77.

24 Bevanda, M., „Ugovor između liječnika i pacijenta“, Zbornik Pravnog fakulteta Sveučilišta u Rijeci, god. 26, br. 1, 2005., str. 331.

25 Čl. 3. Zakona o kvaliteti zdravstvene zaštite. 
vještine, pažnje i kompetencije ili pak kao propuštanje poduzimanja radnji koje predstavljaju medicinski zahvat i koje su trebale biti obavljene sukladno pravilnom i opravdanom standardu dužne pažnje i stručne vještine liječnika temeljene na kompetentnom profesionalnom mišljenju liječnika. ${ }^{26}$ Postupak određenja standarda dužne pažnje liječnika svodi se, in thesi, na razmatranje uobičajenih komponenti koje konstituiraju standard dužne pažnje liječnika kao što su test predostrožnosti, općeprihvaćena (normalna) profesionalna praksa, standard postupanja u vrijeme provođenja medicinskog tretmana, standard postupanja ustanovljen upućivanjem na najnoviju medicinsku praksu i $\mathrm{dr}^{27}$

\subsubsection{Determinacijske komponente pravnog standarda dužne pažnje liječnika}

U pogledu testa predostrožnosti zahtijeva se da svaki rizik kojem bi pacijent bio izložen mora biti opravdan anticipiranim zdravstvenim koristima za pacijenta koje će nastati kao očekivana posljedica poduzete medicinske intervencije. Prema tome, liječnik će postupati prema uobičajenoj (normalnoj) profesionalnoj praksi ako liječenje zasniva na medicinskoj praksi koja je općeprihvaćena kao ispravna od strane stručnog tijela koje utvrđuje medicinska mišljenja u odnosu na pojedina područja medicine. Liječnik će postupati prema očekivanom medicinskom standardu ako primjenjuje medicinsku praksu koju je ustanovila neka određena škola mišljenja bez obzira na činjenicu da istodobno egzistira i drukčija medicinska praksa u istovrsnim medicinskim slučajevima, što ju je ustanovila neka druga relevantna škola stručnog mišljenja. Međutim, liječnik bi odstupio od medicinskog standarda ako bi sebe postavio profesionalno superiornijim u odnosu na postojeće škole mišljenja. Odsustvo liječničke pogreške i uzročne veze postoji i u slučaju kad se štetna posljedica nije mogla svladati usprkos tome što se postupalo s potrebnom pažnjom u skladu s medicinskim standardom, a to je u konkretnom slučaju izostalo. ${ }^{28}$

Jedna od konstitutivnih komponenti pravnog standarda dužne pažnje liječnika, izražena složenicom - standard postupanja u vrijeme provođenja medicinskog tretmana - implicira izvršavanje liječničkih obveza prema primatelju zdravstvene usluge na način i s pažnjom koji uključuju aplikaciju zdravstvenih metoda zasnovanima na aktualnom standardu profesionalne pažnje liječnika, dakle, na takvom standardu dužne pažnje koji odgovara realnom vremenu u kojem se određeni medicinski tretman ili operacija planiraju ili provode. Stalni progres i dinamična narav medicinske znanosti uzrokuju stalnu modifikaciju standarda dužne pažnje liječnika tako da standard pažnje koji je vrijedio u ranijim fazama razvoja medicinske znanosti ne odgovara standardu profesionalne pažnje koji se zahtijeva danas.

Također važna komponenta u konstrukciji standarda dužne profesionalne pažnje liječnika - standard postupanja ustanovljen upućivanjem na najnoviju medicinsku

26 Giesen, op. cit. u bilj. 13, str. 105.

27 Ibid., str. 112-120.

28 VSRH, Rev 876/06-2 od 10. I. 2007. 
praksu - postavlja imperativ profesionalnog postupanja liječnika koje bi trebalo slijediti najnovija dostignuća medicinske znanosti na određenom području, te će u suprotnome biti građanskopravno odgovoran jer nije postupio sukladno zahtijevanom standardu dužne pažnje. Odnosno, biti će odgovoran jer je propustio primijeniti već općeprihvaćenu novu medicinsku metodu koja je obećavala veći uspjeh zdravstvenog zahvata na stanje pacijentova zdravlja, a u odnosu na stariju zdravstvenu metodu koju je u konkretnom slučaju primijenio. U presudi francuskog kasacijskog suda ${ }^{29}$ navodi se kako je liječnik koji je prakticirao homeopatiju postupao s nepažnjom jer je obeshrabrio pacijenta da obavi pregled rendgenom što ga je preporučio liječnik specijalist. Slično tome, Savezni vrhovni sud Njemačke ${ }^{30}$ utvrđuje kako je postupanje liječnika bilo contra legem artis jer je u određenom slučaju tretirao pacijenta starijim lijekom koji je kao prateću pojavu izazvao trovanje arsenom usprkos tome što je u vrijeme poduzimanja tretmana primjena penicilina, kao lijeka koji ne izaziva prateće negativne posljedice na zdravlje, bila općeprihvaćena za takve slučajeve.

\subsection{PRAVNI STANDARD DUŽNE PAŽNJE LIJEČNIKA U HRVATSKOM PRAVU I PRAKSI AD COMPARANDUM}

\subsubsection{Liječnikova dužnost da postupa s povećanom pažnjom - pažnja dobrog stručnjaka}

Hrvatsko pozitivno pravo, kao i usporedna pravna uređenja, gotovo unificirano ustanovljuju temeljne obveza liječnika u obavljanju medicinskog tretmana te napose propisuju dužnost postupanja s povećanom pažnjom, prema pravilima struke i običajima - pažnja dobrog stručnjaka. ${ }^{31}$ Dakle, skrivljeno bi postupio svaki liječnik koji bi medicinski tretman provodio s pažnjom tek osrednjeg ili prosječnog stručnjaka, a u odnosu na postavljeni standard pažnje dobrog stručnjaka. Od liječnika se očekuje da u svom profesionalnom djelovanju postupa s povećanom pažnjom koja osigurava kvalitetu njegove usluge. ${ }^{32} \mathrm{U}$ pravnoj teoriji navodi se da opisani standard pažnje ne bi trebalo shvatiti kao kruto pravilo koje ne trpi odstupanja u praksi već bi se trebalo prilagođavati okolnostima konkretnog medicinskog slučaja bilo u smislu ublažavanja ili pooštrenja standarda dužne pažnje. ${ }^{33} \mathrm{U}$ tom se smislu navodi da veća opasnost i veći rizik zahvata zahtijevaju veću pažnju, a hitnost i nužnost zahvata opravdavaju niži standard pažnje, ${ }^{34}$ pri čemu se niži standard pažnje ne može opravdati praksom koja može biti i dosta raširena ako se radi o neurednom

29 Francuski kasacijski sud (Cour de Cassation), Cass civ 1re, od 4. studenoga 1964.

30 Savezni vrhovni sud Njemačke (BGH), presuda od 16. svibnja 1972. VersR 1972.

Čl. 18. st. 2. ZOO-a, Narodne novine, br. 35/2005, 41/2008.

32 Radišić, J., Odgovornost zbog štete izazvane lekarskom greškom u lečenju $i$ u obaveštavanju pacijenta, Nomos, Beograd, 2007., str. 81.

33 Klarić, P., „Odgovornost zdravstvene ustanove i zdravstvenih djelatnika za štetu“, Hrvatska pravna revija, god. 1, br. 8-9, 2001., str. 74.

34 Deutsch, E., Medizinrecht, 4. Aufl., Springer, Berlin, 1999., str. 124. 
i površnom postupanju odnosno poslovanju, ${ }^{35}$ drugim riječima uvijek se valja pitati kako bi se iskusan i pažljiv liječnik opće prakse ili specijalist ponašao u određenoj situaciji ${ }^{36}$ Vrijedi pravilo da specifične okolnosti konkretnog zdravstvenog slučaja određuju stupanj i opseg medicinskog nadzora. Tako su pravna teorija i praksa suglasne da će liječnik postupiti sukladno zahtijevanom standardu dužne pažnje ako je u izboru dvije ili više prihvaćenih dijagnostičko-terapijskih metoda u pogledu istovrsnog zdravstvenog stanja pacijenta, u konkretnom slučaju primijenio bilo koju od ovih metoda i pružio odgovarajuću zdravstvenu uslugu. ${ }^{37}$ Komparativna praksa o standardu dužne pažnje liječnika naglašava kako u obavljanju liječničke dužnosti valja postupati na medicinski pravilan način, odnosno iskazujući opravdan i stručan stupanj medicinske vještine (reasonable and competent degree of skill). ${ }^{38}$

U kontekstu hrvatskog medicinskog realiteta gdje se zdravstvena djelatnost ostvaruje u različitim organizacijskim formama (zdravstvene ustanove, trgovačka društva koja obavljaju zdravstvenu djelatnost, privatni zdravstveni radnici), kao relevantan pravni standard mogla bi se primijeniti i pažnja dobrog gospodarstvenika i dobrog stručnjaka. ${ }^{39} \mathrm{U}$ svezi s tim, u dijelu pravne teorije pojavila se dvojba radi li se o konkurenciji različitih pravnih standarda, odnosno postoji li u teoriji i praksi stanovito razmimoilaženje glede njihove primjene. Prevladavajuće je stajalište da se, kada se radi o pružanju zdravstvenih usluga, ova dva pravna standarda sadržajno ne razlikuju, odnosno da bi se pažnja pružatelja zdravstvenih usluga i zdravstvenih radnika koji su zaposleni kod njih trebala procjenjivati s obzirom na jedan standard, unutar kojega valja razlikovati pažnju određene specijalizacije. ${ }^{40} \mathrm{~S}$ obzirom na to da pojmovi pažnja dobrog stručnjaka i pažnja dobrog gospodarstvenika predstavljaju pravne standarde apstraktne naravi, sud ih u slučaju spora tumači u skladu s okolnostima slučaja, oslanjajući se na nalaz i mišljenje vještaka medicinske ili druge struke. Naime, uloga vještaka u sudskom postupku se, inter alia, svodi na davanje stručnog očitovanja u odnosu na pitanje dužne pažnje, koje se u parnici pojavljuje kao questio facti, dok se sudski pravorijek temelji na slobodnoj ocjeni nalaza i mišljenja vještaka, pored ostalih questio iuris koje slobodno ocjenjuje.

Prema tome, standard dužne pažnje liječnika koji se zahtijeva prilikom obavljanja medicinskog tretmana mjeri se prema vanjskom, objektivnom standardu koji odgovara postupanju liječnika prosječne vještine koji u obavljanju svoje dužnosti iskazuje potrebna posebna stručna znanja, pri čemu je sasvim irelevantno što je eventualno uslijed nedostatka sposobnosti, znanja ili iskustva, ustvari nesposoban postići zahtijevani standard postupanja, budući da liječnik treba priznati vlastita ograničenja koja se tiču njegove stručne kvalifikacije i iskustva i tamo gdje je to primjereno mora prihvatiti savjet, pomoć, uputu ili superviziju iskusnijeg kolege

35 Ibid., str. 123.

36 Ibid., str. 124.

37 Nikšić, S., Ugovor o zdravstvenoj usluzi, doktorska disertacija, Pravni fakultet, Zagreb, 2007., str. 439.

38 Giesen, op. cit. u bilj. 13, str. 90-91.

39 Čl. 10. st. 1. i 2. ZOO-a.

40 Nikšić, S., op. cit. u bilj. 37, str. 284, 438. 
liječnika ili pak uputiti pacijenta kolegi specijalistu ili u specijalističku kliniku. ${ }^{41}$ Dapače, stvarnost medicinskog tretmana uvijek počiva na sudjelovanju više osposobljenih medicinskih eksperata koji su svaki za sebe posjednici specifičnih teoretskih znanja i jedinstvenih, nepodijeljenih iskustava, te je ukupno ostvareni medicinski standard redovito oblikovan kao rezultanta koordinacije više liječnika koji su, svaki za sebe, nositelji osobnog znanja i umijeća unutar timskog, nerijetko interdisciplinarnog procesa. U svezi s time, u predmetu Wilsher v. Essex Area Health Authority, sud je zauzeo stajalište da ne bi bilo odstupanja od objektivnog standarda dužne pažnje u slučaju kada bi medicinski tretman bio proveden od strane relativno neiskusnog ili tek kvalificiranog liječnika jer ono što se očekuje jest i dalje visok standard dužne pažnje, a varijacije su dopuštene ovisno o funkciji koju liječnik obavlja u timu, a ne u odnosu na iskustvo pojedinog člana liječničkog tima:

"Budući da je predlagateljici pružena liječnička skrb na posebnom odjelu, u ovom slučaju radilo se o neonatologiji, mjerilo je bio visok standard dužne pažnje. Taj standard bi varirao za pojedine djelatnike ovisno o funkciji tih osoba u liječničkom timu koji skrbi za predlagateljicu, no ne bi varirao ovisno o razini iskustva pojedinog člana medicinskog osoblja. Drugi prijedlog, podnesen u ime svih tuženika, skreće pozornost na osobni položaj pojedinog člana medicinskog osoblja na koga je stavljena pritužba. Ono što se od tog člana očekuje jest ono što se razumno može očekivati od osobe istih formalnih kvalifikacija i praktičnog iskustva i ništa više. Ako je to točno, taj prijedlog zahtijeva da standard dužne pažnje na koji pacijent ima pravo varira ovisno o vjerojatnosti zapošljavanja te osobe $i$ uključivanja u tim. Pacijentovo pravo na pritužbu zbog pružanja neodgovarajuće zdravstvene usluge bilo bi suženo u slučaju povjeravanja na skrb liječniku koji je potpuni novak u određenom području medicine (osim ako možda može ukazati na neki propust u nadzoru osobe koja je na višem stupnju u hijerarhiji) u odnosu na isto to pravo kada bi se pacijent našao u rukama liječnika koji je već proveo mjesece na istom odjelu: u skladu s time smanjit će se i izgledi pacijenta za uspjeh u utvrđivanju odgovornosti nadležnog tijela za posljedice bilo kakve pogreške u tretmanu. ““2

U daljnjoj razradi modela dužne pažnje liječnika, koja je podložna nijansiranju, valja opetovati da je liječnik obvezan zdravstvenu uslugu pružiti s povećanom pažnjom, (postupati s onim stupnjem pažnje koji se redovito očekuje od dobrog stručnjaka ili gospodarstvenika u istovrsnim situacijama), pri čemu treba naglasiti da se on ne može opravdati time što je postupao prema svom najboljem znanju, ako se ustanovi da je to znanje za obavljanje njegova zanimanja bilo objektivno nedovoljno. ${ }^{43}$ Dakle, liječnik će odstupiti od standarda dužne pažnje ako nije bio svjestan granica vlastitih profesionalnih mogućnosti te je stoga poduzeo ili nastavio liječenje umjesto da se obratio za savjet drugom liječniku ili da je pacijenta uputio

\footnotetext{
41 Ibid., str. 94.

42 Prema Steele, J., Tort law: text, cases and materials, Oxford University Press, New York, 2007.

43 Koziol, H., Österreichisches Haftpflichtrecht, Band II, Besonder Teil, Wien, 1984., str. 183.
} 
specijalistu, na bolničko liječenje ili u drugu zdravstvenu ustanovu koja ima kvalificiranije liječnike ili je opremljena boljom medicinskom tehnikom. ${ }^{44}$

\subsubsection{Kvalificirani stupanj dužne pažnje liječnika - pažnja dobrog specijalista (eksperta)}

Postavlja se pitanje postoji li raskorak između zahtijevanog standarda dužne pažnje kad je u pitanju liječnik opće prakse, odnosno liječnik specijalist? U teoriji i praksi postoji opći konsenzus oko toga da se u pogledu standarda medicinskog postupanja liječnika opće prakse očekuje postupanje koje odgovara prosječno stručnom liječniku, dok se u pogledu profesionalnog standarda liječnika specijalista ili eksperta, zahtijeva postupanje koje odgovara prosječnom specijalistu ili ekspertu za pojedino medicinsko područje. Razvidno je da liječnik specijalist ili ekspert trebaju prilikom pružanja medicinske usluge postupati s povećanom pažnjom koja je u korelaciji s većim stupnjem stručnog znanja kojim raspolažu. U pravilu, pravni poreci predmnijevaju da je liječnik prihvaćanjem provođenja medicinskog tretmana nad pacijentom implicitno zajamčio da posjeduje odgovarajuće stručno znanje koje mu omogućuje provođenje zahvata nad pacijentom s dužnom pažnjom i stručnošću, što podrazumijeva ispravnu i stručnu procjenu vezanu uz pitanje treba li i kada pacijenta uputiti liječniku specijalistu, u bolnicu ili pak drugom kolegi specijalistu radi drugog liječničkog mišljenja ili daljnjeg medicinskog zahvata.

U ilustrativnom slučaju Pithers v. Leeds Teaching Hospitals NHS Trust iz sudske prakse Velike Britanije, sud je ocjenjivao stupanj dužne pažnje liječnika specijalista te je procijenio kako se u predmetnom slučaju od specijalističkog tima liječnika očekivao visok stupanj pažnje i vještine koja je izostala, što je uvjetovalo nepotpunu dijagnozu i izostanak daljnjeg tretmana:

"Lokalna bolnica uputila je trudnicu na daljnju specijalističku obradu kada je prilikom ultrazvučnog pregleda obavljenog radi otkrivanja fetalnih anomalija uočeno da fetus ima exomphalos i nema mjehura, tj. da postoji sumnja na kloakalnu ekstrofiju, zbog čega je bilo potrebno upućivanje u glavni bolnički centar na poseban specijalizirani odjel. Od tima liječnika specijalista mogao se zahtijevati visok stupanj pažnje $i$ vještine, posebno zato što je postavljeno jasno pitanje: 'Je li prisutna kloakalna ekstrofija ili nije?’. Sukladno tome, specijalistički liječnički tim nije postupio s dužnom pažnjom kad je netočno očitao nalaze. Da je postavljena točna dijagnoza, majka bi izabrala prekid trudnoće. “45

44 Radišić, J., Odgovornost zbog štete izazvane lekarskom greškom u lečenju $i$ u obaveštavanju pacijenta, loc. cit.

45 Vidi predmet: Pithers v. Leeds Teaching Hospitals NHS Trust MLC 1152 (CA: 2004.), Medical negligence, dostupno na: http://www.medneg.com/Case/CaseList.aspx (pristupljeno 8. veljače 2013.). 
Dr. sc. Hrvoje Vojković: Građanskopravni standard medicinskog tretmana

Zbornik radova Pravnog fakulteta u Splitu, god. 56, 3/2019, str. 567-591

\subsubsection{Standard dužne pažnje liječnika u slučaju alternativnih medicinskih postupaka (komplementarna medicina)}

Ponekad se u praksi pojavljuje pitanje kakav standard dužne pažnje in concreto pravo zahtijeva od liječnika kad su u pitanju alternativni medicinski postupci (komplementarna medicina). Iako u korpusu hrvatskog prava i prakse navedeno pitanje dosad nije imalo značaj, poredbena se praksa povremeno bavi navedenom tematikom. Tako je u predmetu Shakoor v. Situ razmatran standard dužne pažnje koja se očekuje od stručnjaka za kinesku biljnu medicinu. Naturopatski liječnik, ekspert za kinesku biljnu medicinu, prepisao je biljni pripravak za pacijentov benigni lipom, a to je konzekventno rezultiralo smrću pacijenta uslijed zatajenja jetre. Vještaci su se složili da je smrt prouzročilo bilje koje je izazvalo "idiosinkratsku" reakciju te da je ta reakcija izuzetno rijetka i nije se mogla predvidjeti ni kod jedne osobe.

Vezano za problematiku standarda dužne pažnje koja bi se zahtijevala u slučajevima medicinskih tretmana koji se obavljaju alternativnim medicinskim postupcima, sud je zauzeo gledište da je fundamentalni orijentacijski kriterij onaj standard postupanja koji se kvalitativno zahtijeva kada je u pitanju zdravstvena usluga koja se obavlja po pravilima ortodoksne, alopatske medicine. ${ }^{46}$

\subsubsection{Povlastica smanjene pažnje}

Prilikom hitnih okolnosti liječnik uživa privilegij smanjenog stupnja pažnje, tj. ne smije se od njega zahtijevati isti stupanj pažnje kao u normalnim okolnostima. ${ }^{47}$ Tako u slučaju nepredvidive i hitne zdravstvene situacije, u uvjetima kada prijeti realna ugroza zdravlja i/ili života pacijenta, liječnik s obzirom na totalitet okolnosti s kojima je suočen kao pružatelj zdravstvene usluge, može unekoliko odstupiti od uobičajenog standarda medicinske usluge, ali u isključivom interesu zaštite zdravlja pacijenta. Slično tome, liječnik ne može jamčiti da će svoje stručno znanje jednako upotrijebiti u svim uvjetima, primjerice, kirurg kojemu za vrijeme operacije postane mučno i uslijed toga načini stručnu pogrešku, može se time opravdati, ${ }^{48}$ ali se ne može opravdati činjenicom da je početnik u struci ili što nije specijalist te stoga nije bio dorastao zahtjevima medicinskog slučaja jer svaki liječnik mora spoznati granice vlastitih mogućnosti. ${ }^{49} \mathrm{U}$ svom razmatranju standarda dužne pažnje liječnika, Savezni vrhovni sud Njemačke u dvije je presude naglasio da standard postupanja "iskusnog kirurga uvijek mora biti zajamčen" ${ }^{50} \mathrm{U}$ okviru njemačke sudske prakse liječnik ne bi počinio pogrešku koja bi vodila povredi pacijentova zdravlja pod

46 Vidi predmet: Shakoor v. Situ MLC 0295 (QB: 2000.), Medical negligence, dostupno na: http:// www.medneg.com/Case/CaseList.aspx (pristupljeno 8. veljače 2013.)

47 Crnić, I., Odgovornost liječnika za štetu, Organizator, Zagreb, 2009., str. 52.

48 Reischauer, R., § 1299, U: Rummel, P. (ur.), Kommentar zum Allgemeinet burgerlichen Gesetzbuch, 2. Band, Manz, Wien, 1984., str. 2212.

49 Radišić, J., Odgovornost zbog štete izazvane lekarskom greškom u lečenju i u obaveštavanju pacijenta, loc. cit.

50 Savezni vrhovni sud Njemačke (BGH), presuda od 10. II. 1987. (VI ZR 68/86) JZ 1987, 877 (D. Giesen). 
uvjetom da je u konkretnom slučaju koristio medicinsko znanje i iskustvo koje se od njega traži, te je slijedom toga donio osnovanu odluku o dijagnostičkim i terapijskim mjerama i ako je te mjere brižljivo proveo. ${ }^{51}$

Neovisno o činjenici da je profesionalni standard dužne pažnje liječnika objektivna, impersonalna kategorija koja se ne može izjednačiti s pojedincem liječnikom, uvijek je valja razmatrati s obzirom na specifične okolnosti obavljanja konkretnog medicinskog tretmana. Kod slučaja uobičajenih okolnosti u kojima se provodi medicinski zahvat, liječnik je dužan u izvršavanju medicinske usluge uzeti u obzir sve moguće medicinske rizike koje je razumno moguće predvidjeti jer u suprotnom odstupa od postavljenog standarda dužne pažnje. Praksa ponekad bilježi situacije u kojima liječnik medicinski tretman provodi u ekstraordinarnim uvjetima koji mu objektivno onemogućuju da uoči sve medicinske rizike koji bi u uobičajenim okolnostima bili predvidljivi ili one u kojima je svjestan mogućih rizika, ali istovremeno i spriječen u tome da ih isključi ili poduzme odgovarajuće mjere predostrožnosti, primjerice, u slučaju epidemije. U takvom slučaju medicinsko postupanje liječnika ne rezultira liječničkom pogreškom, odnosno ne dolazi do odstupanja od standarda dužne pažnje liječnika.

\subsubsection{Liječnikova obveza rada sukladno ars medica - jamstvo stručnosti, ne rezultata}

In fine treba istaknuti da pridržavanje standarda dužne pažnje liječnika u načelu implicira jamčenje stručnosti u punom obujmu, u odnosu na konkretan medicinski slučaj, te da upravo ta činjenica predstavlja fundamentalni sadržaj medicinske i pravne konstrukcije istraživanog profesionalnog standarda postupanja. Ujedno ona predstavlja osnovnu obvezu koja za liječnika (zdravstvenu ustanovu) nastaje iz ugovora o zdravstvenom tretmanu - obvezu rada prema pravilima struke is povećanom pažnjom. Međutim, isto tako se mora naglasiti da liječnik ni u kojem slučaju nije jamac uspjeha poduzetog zdravstvenog tretmana, osim u specifičnim slučajevima kad je ugovorena obveza rezultata, kao, per exemplum, u slučaju stomatoloških i estetskih zahvata. Izneseno gledište potvrđuje poredbena sudska praksa ističući da je liječnik dužan postupati prema općeprihvaćenom standardu dužne pažnje jer će u suprotnom biti građanskopravno odgovoran za nastalu liječničku pogrešku. Dakle, liječnik nije jamac uspjeha niti onaj tko osigurava rezultat ili može spriječiti nastupanje slučajnih pogreški, odnosno smatrat će se odgovornim samo za one pogreške u tretmanu koje se mogu pripisati liječničkoj nepažnji, pri čemu sam neželjeni rezultat liječenja nije sinonim za liječničku nepažnju. ${ }^{52}$

51 Savezni vrhovni sud Njemačke (BGH), presuda od 29. studenoga 1994., Neue JuristischeWochenschrift, 1995., br. 12, str. 777.

52 Giesen, op. cit. u bilj. 13, str. 103. 


\subsubsection{Standard dužne pažnje liječnika u engleskom pravu - Presedani Bolam / Bolitho}

\subsubsection{Standard Bolam}

Istraživanje standarda dužne pažnje liječnika ne može zaobići osvrt na znameniti slučaj iz engleske sudske prakse, Bolam v. Friern Hospital Management Committee iz 1957. godine, povodom tužbenog zahtjeva zbog nestručne primjene elektrokonvulzivne terapije. Presuda u navedenom predmetu postavila je pravni presedan kojim su utvrđeni orijentacijski kriteriji u svrhu upute poroti. Naime, izraženo je stajalište da u slučaju "kada se pacijent ozlijedi tijekom liječenja i postoje razni načini pružanja liječenja, ako je usvojeni način bio u skladu s praksom tada prihvaćenom kao ispravnom od strane odgovornih stručnjaka za medicinu u određenom obliku liječenja, to ne predstavlja nemar“. Ovako utvrđeni standard dužne pažnje liječnika poznat je u pravnoj literaturi kao Bolamov standard te je u širem smislu primijenjen na sve zdravstvene radnike, bez obzira na to jesu li iskusni kirurzi ili nedavno kvalificirani bolnički liječnici, te medicinske sestre. Kao pravno relevantan standard prihvaćen je model postupanja čovjeka prosječne stručne vještine koji u obavljanju svog posla iskazuje tu posebnu vještinu, stručno znanje, ali on nije niti specijalist perfekcije, niti profesionalac „olimpijske reputacije”, već prosječno mjerilo za umjerenost i objektivnost. ${ }^{53}$ Prema tome, liječnik koji posjeduje specijalnu vještinu mora primjenjivati uobičajenu vještinu u okviru te specijalnosti, a pitanje liječničke nepažnje valja in casu speciali razmotriti kroz prizmu sljedećih rukovodnih premisa:

„Kako ocijeniti je li to činjenje ili propuštanje povreda dužne pažnje? U običnom slučaju općenito se kaže da to treba usporediti s onim što bi učinio bilo koji čovjek s ulice. Covjek s ulice je običan čovjek. U jednom slučaju rečeno je da je predmet usporedbe ono što bi učinio srednje obrazovan i prosječno inteligentan laik. Takav čovjek je običan čovjek. No imamo li situaciju koja uključuje primjenu posebne vještine ili sposobnosti, tada za ocjenu je li došlo do povrede dužne pažnje mjerilo nije ponašanje srednje obrazovanog i prosječno inteligentnog laika, jer takav čovjek ne posjeduje posebnu vještinu. Mjerilo je prosječno sposoban čovjek koji vrši radnju za koju je potrebna ta posebna vještina ili se predstavlja kao osoba koja ju posjeduje. Čovjek ne mora posjedovati vještinu najboljega stručnjaka; opće je prihvaćeno da je dovoljno da ima uobičajeni stupanj vještine prosječno sposobnog čovjeka te struke."

U kritici Bolamovog testa u praksi - a nota bene, primjenjivao se dugi niz godina - isticalo se kako je nepošten prema pacijentima jer se obrana tuženika redovito zasnivala na izvođenju dokaza vještačenjem od strane vještaka medicinske struke koji su počesto izražavali prikrivenu kolegijalnu solidarnost s tuženim liječnicima. Posljedično, tužitelji su, u pravilu, bili suočeni s teškim zadatkom pronalaženja vještaka koji bi na sudu otvoreno ustvrdili da je liječenje de facto bilo ispod

53 U obrazloženju presude sudac McNair iznosi da ,gdje postoji situacija koja uključuje korištenje nekih posebnih vještina ili sposobnosti, tada se preispitivanje postojanja ili nepostojanja nepažnje ne svodi na ispitivanje čovjeka koji je na vrhu Claphamovog omnibusa jer on ne posjeduje tu posebnu vještinu. 
standarda zahtijevane dužne pažnje, dok su istovremeno sudovi bili neskloni utvrditi da je dokaz vještaka u korist obrane nelogičan. ${ }^{54}$

\subsubsection{Standard Bolitho}

Nakon četrdeset godina primjene Bolamovog standarda, sudska je praksa provela stanovite korekcije dotadašnje važeće paradigme modela dužne pažnje liječnika. Naime, u čuvenom predmetu, Bolitho v. City of Hackney Health Authority, relativizirana je važnost nalaza i mišljenja vještaka, a ultimativna ocjena eventualnog postojanja povrede standarda dužne pažnje inteligentno je transponirana u isključivu domenu slobodne sudačke ocjene. Novi Bolithov presedan u bitnome je izmijenio dotadašnju faktičnopravnu neravnotežu u odnosu oštećenog pacijenta i liječnika te je značajno doprinio harmonizaciji njihova pravnog položaja u okviru odštetnopravnog postupka, sukladno načelu pravičnosti. ${ }^{55}$ Krucijalni aspekt novoutvrđenog standarda dužne pažnje sastoji se u činjenici da se prilikom ocjene izvedenih dokaza nalaz vještaka više ne smatra odlučnim dokazom ako nije verificiran logičkom analizom, odnosno sud nije obvezan smatrati da se liječnik oslobodio odgovornosti samo zato što vještak smatra da su tuženikovo liječenje ili dijagnoza bili u skladu s dobrom zdravstvenom praksom. U svakom pojedinom slučaju sud se morao uvjeriti da su vještaci svoje stručno mišljenje u stanju dokazati služeći se pravilima logike. ${ }^{56}$

\subsubsection{Odstupanje od građanskopravnog standarda medicinskog tretmana - liječnička pogreška}

U pravnoj literaturi ističe se gledište kako bi pod pojmom liječničke pogreške (medical malpractice) trebalo ocijeniti situaciju u kojoj liječnik nije primijenio medicinski postupak zasnovan na aktualnim spoznajama medicinske znanosti, a koji je s obzirom na konkretne okolnosti objektivno bio neophodan, odnosno, ako ga je primijenio nepravilno te slijedom toga nije postupio s odgovarajućim stupnjem pozornosti koja se općenito zahtijeva od savjesnog liječnika. ${ }^{57} \mathrm{U}$ medicinskoj praksi mogući su različiti oblici liječničke pogreške kao što su: (1) pogreške unutar organizacijskog procesa; (2) pogreške prilikom preuzimanja pacijenta; (3) pogreške koje su posljedica nedostatne suradnje s obzirom na horizontalnu i

54 Prema Vojković, H., Građanskopravna odgovornost za liječničku pogrešku, doktorska disertacija, Pravni fakultet, Zagreb, 2013., str. 305.

55 U citiranom predmetu dvogodišnji dječak zadobio je ozljedu mozga i kasnije preminuo zbog zastoja srca koji je uslijedio nakon zatajenja dišnog sustava. Bio je na brizi bolničkog osoblja i pretrpio je dvije ozbiljne epizode teškoća s disanjem prije konačnog zatajenja dišnog sustava. U oba slučaja medicinske sestre koje su brinule o dječaku pozvale su liječnicu da pregleda dječaka, no ni u jednom slučaju ona to nije učinila. Tužbeni je zahtjev bio zasnovan na tvrdnji da je liječnica trebala dječaku pružiti liječničku skrb, da ga je trebala intubirati nakon prve dvije epizode i da je to učinjeno da bi bilo spriječeno i zatajenje dišnog sustava i zastoj srca. Liječnica je osporavala tužbeni zahtjev inzistirajući na tome da ne bi intubirala dječaka čak i da ga je pregledala, pa slijedom toga njeno propuštanje zbrinjavanja dječaka nije uzrokovalo nastalu štetnu posljedicu.

56 Prema Vojković, H., op. cit. u bilj. 54, str. 306.

57 Ferrara, S. D.; Boscolo-Berto, R.; Viel, G. (ur.), op. cit. u bilj. 1, str. 122. 
vertikalnu distribuciju poslova; (4) izostanak medicinskog tretmana - namjerno ili nemarno propuštanje poduzimanja neophodnog medicinskog tretmana; (5) nepravilan medicinski tretman - terapija koja je u neskladu s aktualnim medicinskim spoznajama. Kao tipične pogreške mogu se izdvojiti: (1) nedostatnost kliničkog, laboratorijskog i drugog istraživanja; (2) pogrešna dijagnoza; (3) pogrešna indikacija; (4) nedostatak kontrole; (5) pogrešna terapija; (6) pogrešne kirurške tehnike; (7) neprepoznavanje medicinskih komplikacija; (7) pogrešna ili nedostatna higijenička praksa; (8) neispravna medicinska oprema; (9) pogreške u rukovanju injekcijama, infuzijom i transfuzijom..$^{58}$

U svakom slučaju, liječničke pogreške koje se pojavljuju tijekom procesa liječenja možemo summa divisio klasificirati na: (1) dijagnostičke liječničke pogreške; (2) terapijske liječničke pogreške koje uključuju pogreške u terapiji i pogreške u provođenju medicinskih zahvata (invazivnih i neinvazivnih), te (3) komunikacijske liječničke pogreške koje nastaju u komunikaciji, odnosno izostanku pravilne komunikacije između liječnika i pacijenta ili liječnika i medicinskog osoblja, bez obzira na aktivni (činjenje, facere) ili pasivni (propuštanje, non facere) modus počinjenja. ${ }^{59}$ Valja napomenuti da su u bogatoj medicinskoj praksi zabilježena i druga atipična odstupanja od medicinskog standarda, koja nisu svrstana u opću tipologiju liječničkih pogreški te se s obzirom na cilj predmetnog istraživanja nisu posebno razmatrala.

Ne postoji jasna definicija termina liječničke pogreške u hrvatskom pravu, ali se sadržaj pojma može odrediti negativno, enumeracijom obveza liječnika tijekom medicinskog tretmana nad pacijentom, koje su utvrđene zakonskim i strukovnim propisima te uvriježenim medicinskim običajima (consuetudo). Utvrđenje pojma zasniva se na činjenici da u supstratu liječničke pogreške stoji postupanje liječnika protivno pravilima zdravstvene struke, odnosno postupanje contra legem artis ili tzv. mala praxis, te također i postupanje liječnika protivno moralnim i etičkim načelima te suvremenim medicinskim standardima. Slijedom iznesenoga, pravna je znanost u hrvatskom pravu liječničku pogrešku definirala kao postupanje liječnika u okviru medicinskog zahvata nad pacijentom, protivno pravilima zdravstvene struke te njenim moralnim i etičkim načelima, odnosno kao postupanje liječnika koje je u neskladu s provjerenim standardima suvremene medicinske znanosti, a što je rezultiralo povredom pacijentova zdravlja ili života, tj. povredom prava osobnosti. ${ }^{60}$ Sukladno tome, pojmom liječničke pogreške valja obuhvatiti i medicinske zahvate koji se provode bez pristanka pacijenta - samovoljno liječenje, i to neovisno o medicinskom ishodu, odnosno, usprkos mogućnosti da je liječenje u svemu provedeno prema pravilima medicinske profesije. Prema tome, pojmom liječničke pogreške mogu se per extensum označiti i gore opisane situacije jer uslijed povrede prava pacijenta na suodlučivanje (informirani pristanak) izravno nastupa šteta u

58 Dettmeyer, R.; Madea, B., „Haftpflicht und Behandlungsfehler“, u: Madea, B. (ur.), Praxis Rechtsmedizin, 2nd ed., Springer, New York, 2007., str. 577-581.

59 Vojković, H., op. cit. u bilj. 54, str. 165.

60 Ibid., str. 140. 
vidu povrede prava na tjelesni integritet, kao jednog od zaštićenih prava osobnosti pacijenta.

\section{ZAKLJUČNE NAPOMENE}

Medicinski standard obavljanja usluge medicinskog tretmana počiva na zahtjevu da liječnik u svakom pojedinačnom slučaju mora poštovati odgovarajući medicinski protokol te da mora primijeniti zahtijevani standard dužne pozornosti koja odgovara njegovoj profesiji. Važno je istaknuti da se medicinski standard ne može diferencirati s obzirom na dob i spol pacijenta ili neke druge kriterije, te se jedinstveno primjenjuje u svojoj punini uz specifičnosti koje dolaze do izražaja u slučajevima autonomije maloljetnog pacijenta, pacijenta bez svijesti, u neodgodivim medicinskim postupcima, ekstraordinarnim situacijama i dr. Ad exemplum, prilikom hitnih okolnosti liječnik uživa privilegij smanjenog stupnja pažnje, tj. ne smije se od njega zahtijevati isti stupanj pažnje kao u normalnim okolnostima. ${ }^{61}$

U svakom slučaju standard provođenja medicinskog tretmana iskazuje se u dimenziji temeljnog ili osnovnog standarda koji pretpostavlja primjenu jednoznačnih pravila kojih se mora pridržavati svaki liječnik, primjerice higijenskih pravila prilikom operativnih zahvata, ali istovremeno u medicinski standard spadaju i svi drugi postupci liječnika koji su rezultat novijih znanstveno-medicinskih spoznaja i primjenjuju se u širem stručnom krugu. Progresivna narav medicine i posljedična dinamička dimenzija uvjetuju stanovite teškoće u finalnoj definiciji medicinskog standarda. Tako u hrvatskom pravu Zakon o zdravstvenoj zaštiti uzima u obzir promjenjivu kategoriju profesionalnog medicinskog standarda i utvrđuje pravo i obvezu zdravstvenih djelatnika da se stručno usavršavaju radi održavanja i unapređivanja kvalitete zdravstvene zaštite. ${ }^{62} \mathrm{Na}$ objektivna aplikativna ograničenja medicinskog standarda ne utječe samo spoznaja da isti predstavlja permanentno promjenljivu kategoriju, već također i činjenica da medicinski standard nema kapacitet upravljanja medicinskim postupkom u njegovu totalitetu s obzirom na pravila profesionalne autonomije liječnika. Naime, liječnik, neovisno o medicinskom standardu, uvijek ima pravo na slobodu izbora odgovarajuće terapije koja se očituje u tri elementa: (1) liječnik odlučuje je li liječenje uopće potrebno; (2) ne smije biti prisiljen primijeniti medikamente ili metode koje proturječe njegovoj savjesti; (3) slobodan je izabrati one dijagnostičke ili terapijske mjere za koje vjeruje da su za konkretnog pacijenta najprimjerenije i najdjelotvornije. Od liječnika se ne zahtijeva izbor najsigurnijeg terapeutskog puta, već bit odgovornog izbora valja tražiti u savjesnom odmjeravanju načela koristi i rizika. ${ }^{63}$

${ }^{61}$ Crnić, Odgovornost liječnika za štetu, loc. cit.

62 Čl. 138. Zakona o zdravstvenoj zaštiti.

63 Laufs, A.; Uhlenbruck, W., Handbuch des Arztrechts, 3. Auflage, Beck, München, 2002., str. 18-19. 
U hrvatskom pravu, medicinsku i pravnu morfologiju važećeg medicinskog standarda, pored ustaljene i općeprihvaćene prakse, u bitnome određuje načelo sigurnosti pacijenata. Navedeno načelo ostvaruje se provedbom mjera kojima se svakom pacijentu osigurava pravo na kvalitetnu zdravstvenu zaštitu sukladno njegovu zdravstvenom stanju i općeprihvaćenim stručnim standardima te kojima se sprečavaju štetni neželjeni događaji čija bi posljedica mogla biti smrt ili oštećenje zdravlja pacijenta. ${ }^{64}$ Uređujući nadalje model ostvarivanja kvalitete zdravstvene zaštite, hrvatsko pozitivno pravo utvrđuje načelo učinkovitosti i djelotvornosti sustava kvalitete zdravstvene zaštite i sigurnosti zdravstvenih postupaka, koje se ostvaruje provedbom mjera za osiguranje kvalitete zdravstvene zaštite čime se postiže optimalan odnos između učinaka provedenih zdravstvenih postupaka i troškova nastalih njihovom provedbom, uvažavajući pritom tehničke, organizacijske i gospodarske čimbenike. ${ }^{65}$

Pravila medicinske profesije zahtijevaju da liječnik postupa pažljivo i stručno što bi mu trebalo omogućiti da postavi ispravnu dijagnozu i uspješno obavi potrebno liječenje. U pogledu pravnog standarda dužne pažnje liječnika, pojedini pravni poreci koriste sintagmu bonus pater familias (Italija, Francuska i Spanjolska), dok drugi (Velika Britanija i skandinavske zemlje) koriste termin razuman liječnički standard $\mathrm{u}$ korelaciji s prihvaćenim pravilima medicinskog umijeća - ars medica. ${ }^{66}$ U svakom slučaju, profesionalna pažnja, odnosno pažnja dobrog stručnjaka određuje se objektivno, a kao objektivno tipizirani standard pažnje uzima se pažnja koja se može očekivati od iskusnog i savjesnog medicinara istog ranga (njemačko pravo), odnosno dobrog stručnjaka iste kategorije i istog ranga kao i onoga čije se profesionalno postupanje ocjenjuje (liječnika opće prakse, specijalista i dr., u francuskom pravu) ili reasonably competent doctor (englesko pravo) ${ }^{67}$ Prema tome, koncepcija pravnog standarda dužne pažnje liječnika koji se zahtijeva prilikom obavljanja medicinskog tretmana, mjeri se prema vanjskom, objektivnom standardu postupanja liječnika prosječne vještine koji u obavljanju svoje dužnosti iskazuje potrebna posebna stručna znanja, pri čemu je sasvim irelevantno što je eventualno uslijed nedostatka sposobnosti, znanja ili iskustva, ustvari nesposoban postići zahtijevani standard postupanja, s obzirom na to da liječnik treba priznati vlastita ograničenja koja se tiču njegove stručne kvalifikacije i iskustva i tamo gdje je to primjereno mora prihvatiti savjet, pomoć, uputu ili superviziju iskusnijeg kolege liječnika ili pak uputiti pacijenta kolegi specijalistu ili u specijalističku kliniku. ${ }^{68}$ Naime, u teoriji i praksi postoji opći konsenzus da se u pogledu standarda medicinskog postupanja liječnika opće prakse očekuje postupanje koje odgovara prosječno stručnom liječniku, dok se u pogledu profesionalnog standarda liječnika specijalista ili eksperta, zahtijeva postupanje koje odgovara prosječnom specijalistu ili ekspertu za pojedino medicinsko područje.

64 Čl. 5. Zakona o kvaliteti zdravstvene zaštite i socijalne skrbi.

65 Čl. 4. Zakona o kvaliteti zdravstvene zaštite i socijalne skrbi.

66 Ferrara, S. D.; Boscolo-Berto, R.; Viel, G. (ur.), op. cit. u bilj. 1, str. 77.

67 Bevanda, ,Ugovor između liječnika i pacijenta“, loc. cit.

68 Ibid., str. 94. 
Postupak determinacije relevantnog pravnog standarda dužne pažnje liječnika svodi se, in thesi, na razmatranje uobičajenih komponenti koje konstituiraju standard dužne pažnje liječnika kao što su test predostrožnosti, općeprihvaćena (normalna) profesionalna praksa, standard postupanja u vrijeme provođenja medicinskog tretmana, standard postupanja ustanovljen upućivanjem na najnoviju medicinsku praksu i dr. ${ }^{69} \mathrm{U}$ pogledu testa predostrožnosti zahtijeva se da svaki rizik kojem bi pacijent bio izložen mora biti opravdan anticipiranim zdravstvenim koristima za pacijenta koje će nastati kao očekivana posljedica poduzete medicinske intervencije. Složenica - standard postupanja u vrijeme provođenja medicinskog tretmana implicira izvršavanje liječničkih obveza prema primatelju zdravstvene usluge na način i s pažnjom koji uključuju aplikaciju zdravstvenih metoda što se zasnivaju na aktualnom standardu profesionalne pažnje liječnika. Pod pojmom standarda postupanja upućivanjem na najnoviju medicinsku praksu implicira se imperativ profesionalnog postupanja liječnika koje bi trebalo slijediti najnovija dostignuća medicinske znanosti na određenom području.

Zaključno treba istaknuti da hrvatsko pozitivno pravo te pravna uređenja ad comparandum, ustanovljuju temeljne obveze liječnika u obavljanju medicinskog tretmana, te napose propisuju dužnost postupanja s povećanom pažnjom, prema pravilima struke i običajima - pažnja dobrog stručnjaka.$^{70} \mathrm{U}$ odnosu na imperativ ostvarenja medicinskog standarda in praxi, od liječnika u hrvatskom zdravstvenom sustavu očekuje se da pri obavljanju medicinske usluge postupa s pažnjom dobrog stručnjaka, odnosno da postupa s povećanom pažnjom, prema pravilima struke i običajima profesije. ${ }^{71}$ Dakle, hrvatsko pozitivno pravo od medicinskog djelatnika traži da postupa prema standardu dobrog, a ne tek prosječnog stručnjaka, a povredu tako nametnutog profesionalnog standarda određuje kao štetnu radnju s obilježjem protupravnosti u subjektivnom smislu, naravno, uz pretpostavku nastanka pravno relevantne štete. Od liječnika se eksplicitno traži da u provođenju medicinskog tretmana postupa prema pravilima zdravstvene struke, tako da svojim postupcima ne ugroze život i zdravlje ljudi, ${ }^{72}$ te da promiču dostojanstveno i odgovorno profesionalno ponašanje poštovanjem propisa, pravila struke i kodeksa medicinske etike i deontologije. ${ }^{73}$

69 Giesen, op. cit. u bilj. 13, str. 112-120.

70 Čl. 18. st. 2. ZOO-a.

71 Ibid.

72 Čl. 124. st. 3. Zakona o zdravstvenoj zaštiti.

73 Čl. 2. st. 2. t. 5. Zakona o liječništvu, Narodne novine, br. 121/2003, 117/2008. 


\section{LITERATURA}

\section{Pravna literatura:}

1. ALLEN, J., Economic Analysis of Medical Malpractice Liability and its Reform, New York University Public Law and Legal Theory Working Papers. Paper 398., 2013.; ,"Contracting over Liability': Medical Malpractice and the Cost of Choice“, University of Pennsylvania, Law Review, 158, str. 957 - 1023, 2010.

2. BEVANDA, M., „Ugovor između liječnika i pacijenta“, Zbornik Pravnog fakulteta Sveučilišta u Rijeci, Vol. 26, br. 1/2005.

3. BUDAK, J., O zdravstvu iz ekonomske perspektive; „Ocjena pacijenata o kvaliteti rada zdravstvenog osoblja“, str. 271-281, Ekonomski Institut, Zagreb, 2014.

4. CRNIĆ, I., Odgovornost liječnika za štetu, Organizator, Zagreb, 2009.

5. DEUTSCH, E., Medizinrecht, Berlin, 1999.

6. DEUTSCH, E., SPICKHOFF, A., Medizinrecht: Arztrecht, Arzneimittelrecht, Medizinprodukterecht und Transfusionrecht, Fünfte, neu bearbeitete und erweiterte Auflage, Berlin (etc.), 2003.

7. FAURE, M.,Economic observations concerning optimal prevention and compensation of damage caused by medical malpractice, Tort and Insurance Law, Vol. 8, European Centre of Tort and Insurance Law, Springer, Wien, New York, 2004.

8. GIESEN, D., International Medical Malpractice Law: A Comparative Study of Civil Liability Arising from Medical Care, J. C. B. Mohr (Paul Siebeck), Tübingen, Martinus Nijhoff Publishers, Dordrecht, Boston, London, 1988.

9. GOLDSTEIN, J., Medical Care for the Child at Risk: On State Supervention of Parental Autonomy, 86 Yale LJ 645 FF, 1977.

10. GRUBB, A. (ed.), Principles of medical law, 2nd ed., Oxford, 2004.

11. KLARIĆ, P. „Odgovornost zdravstvene ustanove i zdravstvenih djelatnika za štetu“, Hrvatska pravna revija, 1:8-9/2001.

12. KOZIOL, H., Oesterreichisches Haftpflichtrecht, Band II, Besonder Teil, Wien, 1984.

13. KULMAN, H. J., „Ubereinstimmungen und Unterschiede im medizinischen, haftungsrechlichen und sozialversicherungsrechtlichen Begriff des medizinischen Standards", Versicherungsrecht, br. 13/1997.

14. LAUFS, A., UHLENBRUCK, W., Handbuch des Arztrechts, 3. Auflage, München, 2002.

15. LOSCH, B., RADAU, W. C., „Das Kind als Schaden-Disskusion“, Neue Juristische Wochenschrift, 12/1999.

16. MILIĆ, D. Obligaciono pravo sa sudskom praksom, br. 33.

17. MUJOVIĆ-ZORNIĆ, H., Neželjeno rođenje djeteta kao slučaj štete, Beograd, 2002.

18. NIKŠIĆ, S., Ugovor o zdravstvenoj usluzi, doktorska disertacija, Zagreb, Pravni fakultet, 2007.

19. PETRIĆ, S., „Građanskopravna odgovornost zdravstvenih djelatnika“, Zbornik Pravnog fakulteta Sveučilišta u Rijeci, Vol. 26, br. 1/2005. 
20. RADIŠIĆ, J., Odgovornost zbog štete izazvane lekarskom greškom u lečenju i u obaveštavanju pacijenta, Nomos, Beograd, 2007.

21. REISCHAUER, R., U: Kommentar zum Allgemeinet burgerlichen Gesetzbuch, 2. Band, Wien 1984.

22. STEELE, J., Tort law: text, cases and materials, New York, 2007.

23. STOLL, H., Haftungsfolgen im burgerlichen Recht, Heidelberg, 1993.

24. TARATINO, U., VIA GIA, A., MACRI, E., ERAMO, A., MARINO, V., MARSELLA, L.T., „Proffesional Liability in Orthopaedics and Traumatology in Italy“, Clinical Orthopaedics and Related Research, 2013.

25. TRAINA, F., „Medical Malpractice: Experience in Italy“, Clinical Orthopaedics and Related Research, 2008.

26. VEDRIŠ, M., KLARIĆ, P., Građansko pravo, 5. izdanje, Zagreb, 2001.

\section{Pravni izvori:}

1. Kodeks medicinske etike i deontologije, Narodne novine br. 55/08

2. Obiteljski zakon, Narodne novine br. 103/15

3. Zakon o kvaliteti zdravstvene zaštite i socijalne skrbi, Narodne novine, br. 124/11

4. Zakon o liječništvu, Narodne novine br. 121/03 i 117/08

5. Zakon o obveznim odnosima, Narodne novine br. 35/05, 41/08

6. Zakon o zaštiti prava pacijenata, Narodne novine br. 169/04

7. Zakon o zdravstvenim mjerama za ostvarivanje prava na slobodno odlučivanje o rađanju djece, Narodne novine, br. 18/78

8. Zakon o zdravstvenoj zaštiti, Narodne novine br. 150/08, 155/09, 71/10, 139/10, $22 / 11,84 / 11,154 / 11,12 / 12,35 / 12,70 / 12$ i $144 / 12$

\section{Pregled sudske prakse:}

Francuska:

1. Francuski kasacijski sud (Cour de Cassation), Cass civ 1re, od 4. studenoga 1964.

Njemačka:

1. Savezni vrhovni sud Njemačke (BGH), presuda od 16. svibnja 1972. VersR 1972.

2. Savezni vrhovni sud Njemačke (BGH), presuda od 29. studenoga 1994., Neue JuristischeWochenschrift, br. 12/1995.

3. Savezni vrhovni sud Njemačke (BGH), presuda od 10. veljače 1987. (VI ZR 68/86) JZ 1987, 877 (D. Giesen)

Republika Hrvatska:

1. VSRH, Rev 1584/1998-2 od 4. veljače 1999. 
2. VSRH, Rev-6/02-2 od 3. srpnja 2003.

3. VSRH, 1808/00-2, od 15. listopada 2003.

4. VSRH, Rev 876/06-2 od 10. siječnja 2007.

SAD i Velika Britanija:

1. Brown v. Lewisham and North Southwark Health Authority MLC 0081 (CA: 1999.), Medical negligence, dostupno na: http://www.medneg.com/Case/CaseList.aspx (pristupljeno 8. veljače 2013.)

2. Gillick v West Norfolk Area Health Authority (1985.)

3. Gillick v West Norfolk and Wisbech AHA (1986.)

4. Groomv. Selby, [2001] EWCACiv522, dostupnona:http://www.surreypersonalinjury. com/resources/law-library/cases/groom-selby-2001/ (pristupljeno 8. veljače 2013.)

5. Mcfarlane and Another (Respondents) v. Tayside Health Board (Appellants), Medical negligence, dostupno na: http://www.medneg.com/Case/CaseList.aspx (pristupljeno 8. veljače 2013.)

6. McLelland v. Greater Glasgow Health Board MLC 0364 (Scotland:2001), Medical negligence, dostupno na: http://www.medneg.com/Case/CaseList.aspx (pristupljeno 8. veljače 2013.)

7. Pithers v. Leeds Teaching Hospitals NHS Trust MLC 1152 (CA: 2004.), Medical negligence, dostupno na: http://www.medneg.com/Case/CaseList.aspx (pristupljeno 8. veljače 2013.)

8. Shakoor v. Situ MLC 0295 (QB: 2000.), Medical negligence, dostupno na: http:// www.medneg.com/Case/CaseList.aspx (pristupljeno 8. veljače 2013.)

9. Rand v. East Dorset Health Authority MLC0172 QBD:2000), Medical negligence, dostupno na: http://www.medneg.com/Case/CaseList.aspx 2013.)

10. Taylor v. Shropshire Health Authority MLC 0226 (QBD:2000), Medical negligence, dostupno na: http://www.medneg.com/Case/CaseList.aspx (pristupljeno 8. veljače 2013.)

Slovenija:

1. Vrhovni sud Republike Slovenije, II Ips 712/2004 od 16. veljače 2006.

2. Vrhovni sud Republike Slovenije, II Ips 736/2005. od 24. svibnja 2007.

3. Vrhovni sud Republike Slovenije, II Ips 99/2006. od 12. lipnja 2008.

4. Viši sud u Mariboru, I Cp 1517/2008 od 4. studenoga 2008.

Srbija:

1. Vrhovni sud Srbije, Rev 2066/88 


\begin{abstract}
Having researched the civil law standard in providing medical treatment, an endeavor was made to assert whether a medical service can be distinguished in qualitative or other terms with respect to a patient's age or sex, or whether it is uniquely and comprehensively administered subject to certain specifics. The medical standard is expressed in the dimension of the fundamental or basic standard which presumes application of precise rules and adhered to by every physician, but at the same time the medical standard also includes other procedures by physicians resulting in newer scientific and medical discoveries and are applied in a wider context of the professional community. When administering a medical procedure, the physician is obliged to act with care as is sought for persons who belong to the same professional circle of people. Accordingly, Croatian law requires that physicians act according to the standard of what is good, and not as merely an average professional, whereas a breach of such an imposed professional standard is determined as a harmful action characterized as unlawful in a subjective sense.
\end{abstract}

Key words: standard of medical treatment, a medical mistake, health service contract, civil liability of doctors, due medical attention, the standard of a good expert 